\title{
H2AC21 Gene
}

National Cancer Institute

\section{Source}

National Cancer Institute. H2AC21 Gene. NCI Thesaurus. Code C162968.

This gene is involved in DNA wrapping and compaction. 